\title{
A Cross-Cultural Analysis of Heart Metaphors
}

\author{
Regina Gutiérrez Pérez \\ Pablo de Olavide University, Seville \\ rgutper@upo.es
}

\begin{abstract}
In this article we propose a cognitive model which results of metaphorical expressions gathered from dictionaries and thesauri and their later examination and classification. We begin with basic conceptual operations, such as reification and personification, to arrive at more complex metaphors which constitute the "Idealized Cognitive Model".
\end{abstract}

\section{Introduction}

This paper studies the conceptualizations of the heart in five languages (three Romance languages, French, Italian and Spanish, and two Germanic ones, English and German). The analysis presented reveals certain similarities and differences in the conceptualizations as a result of cross-linguistic comparisons. We will show these conceptualizations (container for emotions, as an object of value, as central and innermost part, etc.) trying to establish a pattern of similarities and differences among the different cultures.

First of all, we have to explain how metaphor is understood in the field of Cognitive Linguistics. In the realm of Cognitive Linguistics metaphors are "devices that allow us to understand one domain of experience in terms of another” (Lakoff \& Johnson, 1980: 117). The relationship between these domains is unidirectional, since a domain is usually conceived in terms of another and not the other way round (cf. Lakoff, 1993: 245). 
This conception of metaphor highlights its cognitive function to understand and structure experience. Metaphor surpasses the mere linguistic, since it is the main mechanism through which we comprehend abstract concepts.

According to Cognitive Linguistics, there is, on the one hand, the conceptual metaphor, for example the well-known "LOVE IS A JOURNEY" (Lakoff and Johnson, 1980; Lakoff, 1993; Kövecses, 2002: 5), and, on the other hand, metaphorical linguistic expressions. These linguistic expressions are manifestations or instantiations of that conceptual metaphor, as we can observe in the examples taken from Lakoff and Johnson (1980: 44-45) and their translations:

\section{LOVE IS A JOURNEY}

\begin{tabular}{|l|}
\hline Look how far we've come. \\
\hline We're at a crossroads. \\
\hline We'll just have to go our separate ways. \\
\hline We can't turn back now. \\
\hline I don't think this relationship is going anywhere. \\
\hline Where are we? \\
\hline We're stuck. \\
\hline It's been a long, bumpy road. \\
\hline This relationship is a dead-end street. \\
\hline We're just spinning our wheels. \\
\hline Our marriage is on the rocks. \\
\hline We've gotten off the track. \\
\hline This relationship is foundering. \\
\hline
\end{tabular}

Let's see its correspondences in the other languages subject of study:

\section{EL AMOR ES UN VIAJE}

\begin{tabular}{|l|}
\hline Mira qué lejos hemos llegado. \\
\hline Estamos en una encrucijada. \\
\hline Tendremos que emprender caminos separados. \\
\hline Ahora no podemos volver atrás. \\
\hline No creo que esta relación vaya a ninguna parte. \\
\hline ¿Dónde estamos? \\
\hline Estamos atascados. \\
\hline Es un largo camino, lleno de baches. \\
\hline Esta relación es un callejón sin salida. \\
\hline Simplemente estamos haciendo girar la rueda. \\
\hline Nuestro matrimonio encuentra innumerables escollos. \\
\hline Estamos fuera de la vía (Hemos perdido la ruta). \\
\hline Esta relación está yéndose a pique. \\
\hline [Nuestro matrimonio hace aguas.] \\
\hline
\end{tabular}




\section{LIEBE IST EINE REISE}

Schau doch, wie weit wir miteinander gekommen sind.

Wir sind nun am Scheideweg.

Wir müssen jetzt einfach getrennte Wege gehen.

Wir können jetzt nicht mehr umkehren.

Ich glaube, da $\beta$ diese Beziehung nirgendwohin führt.

Wo stehen wir in unserer Beziehung?

Wir sitzen fest.

Es ist ein langer, steiniger Weg gewesen.

Diese Beziehung ist eine Sackgasse.

Bei uns ist im Moment Leerlauf.

Unsere Ehe ist auf Grund gelaufen.

Wir sind auf falsche Gleis geraten.

Unsere Beziehung ist im Begriff unterzugehen.

\section{L'AMORE È UN VIAGGIO}

Guarda come siamo andati lontano.

Siamo a un bivio.

Ora abbiamo solo da separare le nostre strade.

Non possiamo tornare indietro ora.

Non credo che questo rapporto stia andando da nessuna parte

Dove siamo?

Siamo bloccati.

É stato un lungo cammino accidentato.

La relazione è in un vicolo cieco.

Il nostro matrimonio sta andando a picco.

La nostra relazione sta affondando.

\section{L'AMOUR EST UN VOYAGE}

Regarde à quel point noun en sommes arrivés.

Nous sommes à la croisée des chemins.

Nous avons fait un long chemin ensemble et maintenant nous allons suivre des chemins distincts.

Nous ne pouvons plus revenir en arrière.

Je pense que notre relation ne mène nulle part.

Où en sommes-nous?

Nous nous enlisons.

C'est une route longue et tortueuse.

Notre amour est dans une impasse.

Cette relation tourne à vide.

Notre mariage passe un mauvais cap. 
Nous avons déraillé.

Cette relation va somber.

We can observe that the conceptualization of love as a journey is common in the languages subject of study. The journey can be undertaken by car ("This relationship is a dead-end street"), by train ("They are derailed"), by boat ("Our marriage is on the rocks"; "This relationship is foundering”), by plane ("We are just taking off”), etc. In Lakoff and Johnson's (1980: 44-45), "love” is understood in terms of a "journey", and a set of systematic correspondences is established: "The lovers correspond to the travellers", "The love relationship corresponds to the vehicle", "The lovers" common goals correspond to their common destinations on the journey", and "Difficulties in the relationship correspond to impediments to travel”. Conceptual metaphors underlie metaphorical linguistic expressions. So, metaphor is not just a figure of speech, as was claimed by the traditional theory, but, as the cognitive theory states, it is a figure of thought that pervades our everyday language.

Our knowledge about journey allows us to understand those correspondences in love. Likewise, there is a series of conceptual implications (entailments), which are the result of those basic correspondences. In this sense, if love is conceptualized as a journey and the vehicle corresponds to the relationship, then our understanding about the vehicle can help us understand love relationships. As Kövecses (2005: 7) exemplifies:

If the vehicle breaks down, we have three choices: (1) we get out and try to reach our destination by some other means; (2) we try to fix the vehicle; or (3) we stay in the vehicle and do nothing. Correspondingly, if a love relationship does not work, we can (1) leave the relationship; (2) try to make it work; or (3) stay in it (and suffer).

The concept of love can be understood in many different ways: as a physical force (electromagnetic, gravitational, etc.), magic, illness, madness, war, etc. (Cf. Lakoff and Johnson, 1980: 49).

If we ask someone what image he associates with love, there is no doubt that a heart would immediately come to his mind ${ }^{1}$. The image schematic structure of the heart is basically a container for emotions, among these love is the outstanding one, but we will see that the heart also conceptualizes other emotions such as compassion, courage, kindness, etc.

\section{Methodology}

In order to carry out a systematic analysis of the heart we begin with the material documented in monolingual and bilingual dictionaries and other lexicographical works, such as dictionaries of idiomatic expressions and thesauri, since there we find a detailed description of the metaphorical systems of the languages in question. As Deignan (1999: 197) points out: 
... the investigation of a particular semantic field can be made more systematic with the use of a comprehensive thesaurus. It is conceivable that in the future linguistic metaphor databases based on concordance data might be set up along lines of on-line thesauri or dictionaries.

Given that most of the expressions are taken from dictionaries and other reference works, it follows that they are conventionalized expressions and constitute an integral part of the way speakers think and express themselves daily. As Kövecses (1991: 30) comments regarding his methodology in the classification of the conceptual metaphor of happiness:

...in order to be able to arrive at [the] metaphors, metonymies, and inherent concepts, and, eventually, [the] prototypical cognitive models, one needs to study the conventionalized linguistic expressions that are related to a given notion.

To carry out our purpose of comparing metaphors in five languages, we use the methodology proposed by Barcelona (2001) regarding the identification and description of the conceptual metaphor. To do that, we follow a series of parameters that he establishes:

1. Existence or absence of metaphorical projection: Barcelona (2001: 137) defines it in the following way: "The same metaphor may be said to exist in both languages if approximately the same conceptual source and the target can be metaphorically associated in the two languages".

2. Grade of conceptual elaboration: This is the second type of contrast that we can encounter when we compare conceptual metaphors in two or more languages. As Barcelona (2001: 137) puts it: "differences between both languages owning to the existence of a version of the metaphor in one language and its absence, or limited use, in the other".

3. Grade of linguistic conventionality: An expression is conventionalized in a language if it is used frequently by the speakers. Therefore, it opposes to novel metaphors. The object of our study has been a series of conventionalized metaphors.

Soriano (2003: 109) adds a fourth parameter (she points out that Barcelona (2001) does not exclude it explicitly) named "grade of linguistic exploitation", which refers to the productivity of a projection in a particular language. This productivity is measured by the number of expressions resulting from that projection.

We arrive at the conclusion that there exists the same conceptual metaphor in two or more languages when we have gathered a certain number of expressions that illustrate it in those languages. If the expressions found are the same or very similar, then, the superior level, that is, the conceptual metaphor is equivalent, since they correspond to the same conceptualization of reality. The really interesting and novel thing in this field consists of proving that some expressions, which are not completely the same in their structure or meaning, in two or more languages, are based on the same metaphor, since 
they are the reflection of a superior category. As Barcelona (2001: 137) points out, we are dealing with the same metaphor "even though the elaborations, the specifications and corresponding linguistic expressions of the metaphor are not exactly the same, or equally conventionalized, in both of them".

Lakoff argues that our thought processes operate over "Idealized Cognitive Models" (ICMs) of the world. ICMs are said to be "directly embodied with respect to their content ... [usually] with respect to use," and they, "structure thought and are used in forming categories" (1987: 13). As opposed to abstract classical categories, they are said to be derived from our everyday interactions with the world. Later on he adds: "Our basic claim will be that prototype effects result from the nature of cognitive models, which can be viewed as "theories" of some subject matter" (1987: 45). Therefore, the concept of "Idealized Cognitive Model" is understood as a complex structure which can, as we will see, be composed of several metaphors and metonymies which can be related and can constitute folk theories of specific abstract fields, as we will prove in our study.

Along our investigation we have faced the issue of assigning the target domains, since the assignment of an expression to a concrete target domain could be subjective. This corresponds to the formulation of metaphors (cf. Baldauf, 1996, 1997). We hold that, in fact, the decision of choosing a specific target domain depends on the researcher who undertakes the analysis. So far, it does not seem that we can do without personal intuition, once we want to formulate conceptual metaphors. We would like to emphasize that our formulations should be understood as proposals and there is the possibility of arriving at different interpretations. However, we guide ourselves by the procedure followed by Dobrovol'skij (1995), who proposes to use basic categories (taxa, in his terminology), what in our study corresponds to the target domains of "love”, "kindness”, "generosity”, “sadness”, “worry”, “intelligence”, etc., since they are basic level concepts, in the sense of Rosch (1973, 1975, 1977, 1978; Rosch and Mervis, 1975; Rosch et al., 1976). The taxa constitute semantic fields which can overlap, that is, an idiomatic expression may belong to several categories, especially those which are peripheric members. In order to avoid that, we present one expression (two or three, in some cases) as the prototypical member of each category.

Following these initial considerations, we offer the corpus subject of study, obtained from dictionaries (monolingual, bilingual, and dictionaries of idiomatic expressions) and thesauri (cf. Bibliographical references).

\section{Analysis}

\subsection{The heart is a container of emotions}

The word "heart" comes from the Latin cor, cordis. So, Spanish (corazón), French (coeur) and Italian (cuore) take the Latin root, while German (Herz) and English (heart) take the Greek one (kardia). The Indoeuropean root ${ }^{*} \mathrm{kr}$ - has the original sense of "vibrating". 
The Spanish term is the only one which differentiates itself partially from the others, since it is an augmentative, as a result of the medieval conception of the heart as the seat of courage. According to the Diccionario crítico etimológico castellano $e$ hispánico (1980), this word alluded primitively to the big heart of the man and of the woman-lover.

Emotions are the most basic thing of the human being and, therefore, they constitute something intrinsic to our lives. Above all, the heart stands out for being considered the place where they are located. Therefore, we can establish the metaphor "THE HEART IS A CONTAINER OF EMOTIONS". Among them, love is the outstanding one. However, the fact that emotions are located in this body part does not constitute a universal, since there are other languages and cultures in which they are metaphorically reificated in other body parts. Turkish, for example, locates them in the liver, that is why the expression "My liver, my soul" may be striking to us. Another case is Nigerian English, language which considers the belly the seat of emotions (cf. Bauer, 1973).

The cultural differences are due, most of the time, to the metaphorical location of certain faculties or states (like the intellect or the emotion) in the body, since some populations associate internal organs with specific faculties. Sometimes, different cultures do not share those associations (cf. Enfield and Wierzbicka, 2002), as we have just seen, and those differences are reflected on the language in a later stage.

The heart, being the place where feelings are located figuratively, opposes the "head", place where the reason is conventionally placed. Therefore, someone who is led by his heart refers to a person who pushes that main capacity of the intellect into the background in order to give free rein to his feelings.

As it is well known, metaphor is a useful means of expressing one thing in terms of another. Consequently, when it is difficult to express something we resort to it. Therefore, it is self-evident that such a rich field as emotions would make a frequent use of this expressive means and, if we consider the heart as its nucleus, it is no wonder that we find a great number of metaphoric and metonymic expressions with this organ as a source domain.

\subsubsection{The heart is the seat of love}

We have already commented that the heart is essentially associated to love. Related to this emotion, the number of existing metaphors surpasses all the emotions (Martín Morillas, 1998) ${ }^{4}$. Likewise, Kövecses (2000) points out that the concept of love is the most metaphorically used, probably because it does not only allude to an emotion, but also to a relationship. In this sense, it shares source domains which characterize human relationships. According to him, the conceptual metaphors of love that manifest themselves in everyday language are the following (2000: 26):

LOVE IS A NUTRIENT: I am starved for love.

LOVE IS A JOURNEY: It's been a long, bumpy road.

LOVE IS A UNITY OF PARTS: We are as one. They are breaking up. We're inseparable. We fused together. 
LOVE IS CLOSENESS: They're very close.

LOVE IS A BOND: There is a close tie between them.

LOVE IS A FLUID IN A CONTAINER: She was overflowing with love.

LOVE IS FIRE: I am burning with love.

LOVE IS AN ECONOMIC EXCHANGE: I'm putting more into this than you are.

LOVE IS A NATURAL FORCE: She swept me off my feet.

LOVE IS A PHYSICAL FORCE: I was magnetically drawn to her.

LOVE IS AN OPPONENT: She tried to fight her feelings of love.

LOVE IS A CAPTIVE ANIMAL: She let go of her feelings.

LOVE IS WAR: She conquered him.

LOVE IS SPORT/ A GAME: He made a play for her.

LOVE IS A DISEASE/ AN ILLNESS: I am heart-sick.

LOVE IS MAGIC: He was enchanted.

LOVE IS INSANITY: I am crazy about you.

LOVE IS A SOCIAL SUPERIOR: She is completely ruled by love.

LOVE IS RAPTURE/ A HIGH: I have been high on love for weeks.

THE OBJECT OF LOVE IS APPETIZING FOOD: Hi, sweet-pie.

THE OBJECT OF LOVE IS A SMALL CHILD: Well, baby, what are we gonna do?

THE OBJECT OF LOVE IS A DEITY: Don't put her on a pedestal. He worships her.

THE OBJECT OF LOVE IS A VALUABLE OBJECT: You're my treasure!

Later on Kövecses (2000: 123) adds that love abounds in a great number of metonymies. Linguistic expressions which describe physiological, expressive or behavior reactions can be considered metonymies, in the sense that there is a relation of representation between these and the concept of love (relation part-whole). If someone is described with such expressions, we can infer that he is in love. Kövecses enumerates the following:

INCREASE IN BODY HEAT STANDS FOR LOVE: I felt hot all over when I saw her.

BLUSHING STANDS FOR LOVE: She blushed when she saw him.

DIZZINESS STANDS FOR LOVE: She's in a daze over him. I feel dizzy everytime I see her.

PHYSICAL WEAKNESS STANDS FOR LOVE: She makes me week in the knees.

SWEATY PALMS STAND FOR LOVE: His palms became sweaty when he looked at her.

INABILITY TO BREATHE STANDS FOR LOVE: You take my breath away.

INTERFERENCE WITH ACCURATE PERCEPTION STANDS FOR LOVE: He saw nothing but her.

INABILITY TO THINK STANDS FOR LOVE: He can't think straight when he is around her. PREOCCUPATION WITH ANOTHER STANDS FOR LOVE: He spent hours mooning over her. PHYSICAL CLOSENESS STANDS FOR LOVE: They are always together.

INTIMATE SEXUAL BEHAVIOR STANDS FOR LOVE: She showered him with kisses. He caressed her gently.

SEX STANDS FOR LOVE: They made love. 
LOVING VISUAL BEHAVIOR STANDS FOR LOVE: He can't take his eyes off of her. She's starry-eyed.

JOYFUL (VISUAL) BEHAVIOR STANDS FOR LOVE: Her eyes light up when she sees him. He smiled at her and the world stood still.

INCREASE IN HEART RATE STANDS FOR LOVE: He's a heart-throb.

Love is an emotion which affects so deeply the human being that an endless number of metaphors has been elaborated. It would be enough to have a quick look at literature or just at the lyrics of songs. The metaphors collected in this study are the ones which show a great systematicity and conform to a complex metaphorical model.

The first indispensable metaphor in order to be able to refer to an abstract concept is called reification. This consists of attributing characteristic properties of objects to concepts, once turned into discrete entities. In this sense love, symbolized in the heart, is taken as a valuable object. As such, it is delicate and fragile and, as a consequence, it is breakable. As we know, someone has a "broken heart" due to an unhappy love affair, translated in the other languages as:

Sp. Tener el corazón roto

It. Avere il cuore spezzato

Fr. Avoir le cœur brisé

Gr. Das Herz gebrochen haben

Therefore, we can coin the metaphor “THE HEART IS A BREAKABLE OBJECT”. Being granted the condition of object, the heart can own its typical features and be treated as such. In this last sense, it is possible to "possess" someone's heart or "give it" in a love relationship.

\subsubsection{The heart is sincerity}

In relation with this feeling, we find the following expressions:

Eng. From the bottom of one's heart

Sp. Desde lo más profundo del corazón

It. Dal profondo del cuore

Fr. Du/ au fond du coeur

Ger. Aus tiefstem Herzem/ im Grunde seines Herzens ${ }^{5}$

The feelings associated to these expressions are sincere and intense. In English, we even find a use that could be considered hyperbolic: "In one's heart of hearts".

Here again the heart is conceptualized as a container from which sincere feelings, which are usually hidden, emanate.

Another expression associated to the concept of sincerity is:

Eng. To speak from the heart 
Sp. Hablar con el/ de corazón

It. Parlare col cuore

Fr. Parler à coeur ouvert/ parler (du fond) du coeur

Ger. Von Herzen/ aus dem Herz sprechen

In Spanish, there exists the expression "hablar con el corazón en la mano". It is equivalent to the Italian "parlare col cuore in mano". Such an image could be attributed to the fact that the person, in order to clearly show his feelings, figuratively takes the heart out of his breast and shows it on his hand, where it is more easily seen. The same happens in English with the expression "To wear one's heart on one's sleeve", which finds its explanation in the chivalry tradition of the Middle Ages, when the jousts took place in the King's court and the knight dedicated his fight to a woman. She would give him a garment, usually a ribbon, as a sign of her love, and the knight would tie it to his arm, and in this way he would show that he loved her or that he would defend her honour. This is the explanation why nowadays this expression is used with the meaning of clearly showing one's emotions or feelings. This is a case of metonymy, since "heart” stands for "lover".

Therefore, a diachronic perspective can help us reveal the meaning of some expressions that came to light in a particular synchronic moment as a result of its literature, history, beliefs, etc.

\subsubsection{The heart is worry}

The heart can experience worries, concerns and even interest, as the following expressions show:

Eng. To have something at heart

It. Stare a cuore

Fr. Tenir à coeur

Ger. Etwas am Herzen liegen

There is no equivalence in Spanish. It would be translated as "preocuparse por algo".

In English, one's heart even "goes out to someone”. Deignan (1995: 8) explains that "If your heart goes out to someone, you sympathize very deeply with their problems", and she cites the following examples: "My heart goes out to this compassionate man. How could anyone see him as a criminal?”; "Her sincerity and her unhappiness were clear and his heart went out to her”.

\subsubsection{The heart is sadness}

As we have previously commented, emotions give rise to a big number of metaphors. The feelings of sadness or anger (among others) can manifest themselves as:

Eng. To take something to heart 
Sp. Tomarse algo muy a pecho

It. Prendere qualcosa a cuore

Fr. Prendre quelque chose à cœur

Ger. Sich etwas zu Herzen nehmen

The feeling of something pressing, resulting in the difficulty to breathe is the same in all languages. The emotional locus is placed in the heart in French, Italian, German, and English, while in Spanish it is located in the breast. As we can observe, it may be the case that some languages share the same conceptual metaphor, but it could be elaborated in a different way in different codes, i. e, they are different linguistic instantiations, as we have just seen in Spanish. There is no equivalence of the linguistic expression; however, the conventional projection is the same in all languages.

Likewise, due to the feeling of sadness, in Italian the heart cries:

"Mi piange il cuore per".

The heart, reached by Cupid's arrows, can be wounded, and as a consequence, it may even bleed, as it happens in English and German ${ }^{6}$ :

Eng. It makes my heart bleed

Ger. Mein Herz blutet

The metaphor of the wound is found, in general terms, in those cases when something causes a big impression. It is therefore related to the metaphor of the blow, which belongs to the first phase of Ungerer and Schmid's classification: "THE EMOTION COMES SUDDENLY FROM THE OUTSIDE", as such it is conceptualized as a blow.

\subsubsection{The heart is desire}

As a living organism, the heart can even experience desire in English, French and German:

Eng. To a heart's desire; to one's heart's content/ delight ${ }^{7}$

Fr. À cœur joie

Ger. Nach Herzenlust

In Italian, it would be translated as "A sazietà, in quantità, a piacere, a volontà", and in Spanish as "hasta saciarse, a discrección, a placer, a su antojo".

In French, we find the expression "avoir le coeur à faire quelque chose", means "to feel like something; to be in the mood of", usually used in negative, as in:

“Je n'ai pas le coeur à plaisanter”. 
There is projection neither in English, in Italian nor in German. It would be translated as:

Sp. Tener ganas de; estar para.

It. Non sentirsela di fare qualcosa.

Ger. Lust haben, etwas zu tun.

With the same meaning, we find the French expression "à contrecoeur", which means "reluctantly, unwillingly". It corresponds to the Italian "a malincuore".

As a conclusion of this section, we can say that the heart, in the sense that it experiences desire ("To a heart's desire"), cries ("Mi piange il cuore per te"), bleeds ("Mein Herz blutet”), etc., is conceptualized as a "living organism” (cf. section 4).

\subsubsection{The heart is courage}

The heart is used in conventional expressions to symbolize courage and state of mind. In English, discouragement is conceptualized as loss of heart:

To lose heart

This sense is not captured in the same way in all languages, since in the Romance ones it is expressed with verbs containing the root of the word "heart", that is, "cor":

Sp. Descorazonarse

It. Scoraggiarsi (perdere coraggio)

Fr. Se décourager (perdre courage)

German, for its part, expresses it with the word "Mut”, which means "courage”:

Den Mut verlieren

On the other hand, the English and the German "take heart" in order to cheer up:

Eng. To take heart

Ger. Sich ein Herz fassen (Mut fassen/ schöpfen)

In the Romance languages, it is again expressed with verbs or phrases containing the word "heart":

Sp. Reconfortarse

It. Rincorarsi (prendere/ acquistare coraggio)

Fr. Se réconforter ((re)prendre courage) 
We can observe that the Spanish word "coraje", the Italian "coraggio", the French "courage" and the English "courage", derive from the Latin cor, which means "heart". The explanation of it comes from Ancient times, especially the Middle Ages, since courage was placed in the heart, symbol of warlike virtue. From this, the meanings of expressions such as the English "to pluck up courage", the Spanish "hacer de tripas corazón", the French "avoir du coeur au ventre" and "donner (mettre, remettre) du coeur au ventre à quelqu'un", can be easily deduced.

The symbolic meaning of the heart as the seat of courage still exists. In Spanish someone with a "small heart" is someone who gets easily frightened. The English expression "Not to have the heart to do something" is another example of it. It is translated in a similar way in Italian "Mi mancò il cuore", and in French "Le coeur m'a manqué”.

According to the metaphor "SAD IS DOWN", the lack of spirit is conceptualized as a downwards projection. This metaphor gives sense to expressions such as "Her heart sank". This one is similar to the Spanish "se le cayó el alma a los pies", and the German "Ihr Mut sank", in which we also find a downwards projection. The proverb "Faint heart never won fair lady" can also be explained through the same metaphor.

This lack of spirit conceptualized as a downward movement can even project itself on garments, as in German "Das Herz fiel/ rutschte ihm in die Hosen" or in English "His heart was in his boots". Both garments ("trousers" in German and "boots" in English) are placed in the lower part of the body.

Finally, we have to point out that the heart associated to certain animal represents the presence or lack of courage. Obviously, it is not the same to have "a heart of lion", brave and fierce animal par excellence, than to have a "chicken heart", animal commonly associated to cowardice.

\subsection{The heart is a material}

\subsubsection{Materials}

It is a common place in our culture to associate the heart to several materials. For example, related to gold it symbolizes the virtues that can be found inside us, as goodness or kindness, and those virtues are conceptualised are riches. This reification is present in the five languages:

Eng. To have a heart of gold

Sp. Tener un corazón de oro

It. Avere un cuore d'oro

Fr. Avoir un coeur d'or

Gr. Ein goldenes Herz haben/ ein Herz aus Gold haben

Negative connotations are, however, more numerous. We find expressions like:

Eng. To have a heart of stone 
Sp. Tener un corazón de piedra

It. Avere un cuore di pietra

Fr. Avoir un coeur de pietre

Gr. Ein Herz aus Stein haben

There is an exact equivalence in the five languages with other materials, such as iron, steel, marble, etc. Metaphorically, we associate those materials to the heart when we refer to negative feelings. Someone who has a heart of stone, iron, steel, marble, etc., refers to someone who is not easily moved and does not harbour feelings of sensitivity, compassion, sympathy or interest for others. The hardness of the material corresponds to the hardness or coldness in attitude, as we can also observe in the following expressions:

Eng. To be hardhearted

Sp. Ser duro de corazón

It. Essere duro di cuore

Gr. Hartherzig sein

The French say "avoir un coeur de pierre".

The opposite would be:

Eng. To be soft/ tenderhearted

Sp. Ser una persona de buen corazón o de corazón blando

It. Essere di buon cuore/ avere il cuore tenero

Fr. Avoir du cœur/ bon cœur/ le cœur tendre

Gr. Weichherzig sein/ ein weiches Herz haben

Someone who has such a heart possesses qualities like kindness or generosity.

\subsubsection{Size}

Another basic reification consists of granting the heart a particular size. Ruiz de Mendoza (1999: 19) offers a description of the cognitive model of size, which consists of the following features:

(a) Objects vary in size, ranging from very small dimensions to very big ones.

(b) A small object seems to be more controllable than a big one.

(c) A small object seems to be potentially less harmful than a big one.

(d) A small object seems to be potentially less important than a big one.

According to this author, this cognitive model has an experiential basis which arises from our interaction with big and small objects, and it makes us take different perspectives about them, what can produce diverse generalizations; among them, small 
objects are controllable and less important and big ones are less controllable and important.

From this cognitive model it follows that the largeness of the heart has positive connotations, like kindness or generosity, as it is illustrated in the following examples of our corpus:

Eng. To have a big heart

Sp. Tener un gran corazón

It. Avere un gran cuore/ cuore grande

Fr. Avoir un grand coeur

Gr. Grossherzig sein/ ein grosses Herz haben

As we see it, this metaphor has an evident metonymic basis. The relevant fact, however, is not that a part (the heart) is used to represent a whole (the person), but the metaphorical conception of choosing a particular feature of the person (kindness, generosity) that is associated with a part of that whole. Related to this, IbarretxeAntuñano (1999: 34) talks about the "Property Selection Processes" (PSPs): “i.e. the selection in the target domain of only some of those prototypical properties that characterize the physical source domain”.

Later on, she adds (1999: 38):

It is precisely by this selection of properties from the source domain in the target domain that metaphorical mappings are constrained. The properties selected in the target domain must be part of the properties identified in the source domain and no others.

The heart is conceptualized as a container, the larger the size, the more feelings it harbors. In Spanish, we find the hyperbolic expression "No caberle a alguien el corazón en el pecho". Here, however, the heart is the content of the container "chest". That person's happiness, kindness or generosity is so big that his heart does not find enough place in his chest.

On the other hand, the smallness or absence of heart has negative connotations. The meaning of the following expressions is easily deduced from this:

Eng. He has no heart

Sp. No tiene corazón

It. Lui non ha cuore

Fr. Il n'a pas de coeur

Ger. Er hat kein Herz

Related to the cognitive model of size, the heart can even swell in English and Italian. In English, the most frequent is that the heart "swells with pride". In Italian, it can have a positive connotation, as in: "Avevo il cuore gonfio di gioia: My heart was full of joy", or a negative one: "Avevo il cuore gonfio di dolore: My heart was heavy with grief". 
On the contrary, the heart can also shrink. In Spanish, it means to experience pity or sympathy: "Se nos encogía el corazón al ver el reportaje sobre las víctimas de la droga”. (Diccionario fraseológico del español moderno (1996: 63)). It also means "to fear”: "Se le encoge a uno el corazón al ver de tan cerca el precipicio". Likewise, the Grande Dizionario di Spagnolo (2004: 1447) quotes the expression: “(Sentirsi stringere) il cuore: [someone's heart shrinks]". In the same way, the Italian noun "stretta”, which means "hold, grip", has the figurative meaning of "sorrow, grief”, as in the expression "sentì una stretta al cuore: my heart missed/skipped a beat”.

The French expression "avoir le coeur serré" which is translated as "with one's heart in one's throat" is also related to the cognitive model of size. "Serrer" means "to grip, to clasp" (as in "serrer les dents: to clench one's teeth"). In a figurative sense it means "to oppress, to squeeze", as in "son coeur se serre: [his heart shrinks]".

Therefore, when the heart "expands", it has positive connotations, while when it "shrinks", it has negative ones. Small is conceptualized as negative, while big is conceptualized as positive.

\subsubsection{Temperature}

Temperature is another factor to take into account, since it has consequences on the figurative uses of the heart. The cold-hot duality has negative and positive connotations respectively, which are motivated by the effect that these sensations have on the body, as can be proved by the following English expressions: "To be warm-hearted"; "Heartwarming" as in "It was heart-warming to see how pleased the child was".

To this respect Deignan (1995: 161) points out: "Whereas heat is usually used to talk about emotions which are strong and often negative, warm is used to describe emotions that are friendly, caring, and positive”.

English corresponds to German “warmherzig sein”. There is no figurative equivalent in the Romance languages:

Sp. Ser afectuoso, cordial

It. Essere affettuoso, cordiale

Fr. Être sensible, affecteueux, magnanime

On the other hand, the expressions related to cold have negative connotations, as in:

To have a cold heart/ to be coldhearted ${ }^{10}$

Again, the English expression is equivalent to the German "kaltherzig sein". In the other languages it would be translated as:

Sp. Ser frío, insensible

It. Essere insensible, indifferente

Fr. Être dur, froid, indifférent; Avoir du sang-froid 
These have an easy explanation, since we fight the cold due to the discomfort it causes $^{11}$.

In the other languages there is not an exact metaphorical projection in the adjectival compound uses, however, we find similar projections in phrases like "tener un corazón de hielo", in Spanish; "avere un coure di ghiaccio", in Italian, and "avoir un coeur de glace", in French; all of them derive from the same conceptualization.

In English, the heat even softens the heart: "It has warmed the cockles of my heart".

As we all know, the heart opposes the head, since the latter is the seat of reason and the former is the seat of emotions. We also find this contrast in relation to temperature. Therefore, it is easy to deduce the meaning of an expression as "to keep one's head cool".

The use of thermal metaphors to refer to people's character is, in fact, one of the most widespread (Escandell Vidal, 1993: 228).

If emotions are "hot", and their absence is interpreted as coldness, we could argue in favour of a metonymic basis of the previous metaphors, according to the metonymic principle "THE PHYSIOLOGICAL EFFECTS OF AN EMOTION STAND FOR THAT EMOTION", since bodily temperature rises when we experience emotion.

\section{The heart is a living organism}

Ungerer and Schmid (1996: 140), basing themselves on Kövecses' several publications, establish a series of metaphors and metonymies in relation to the category of emotion, which we put forward below:

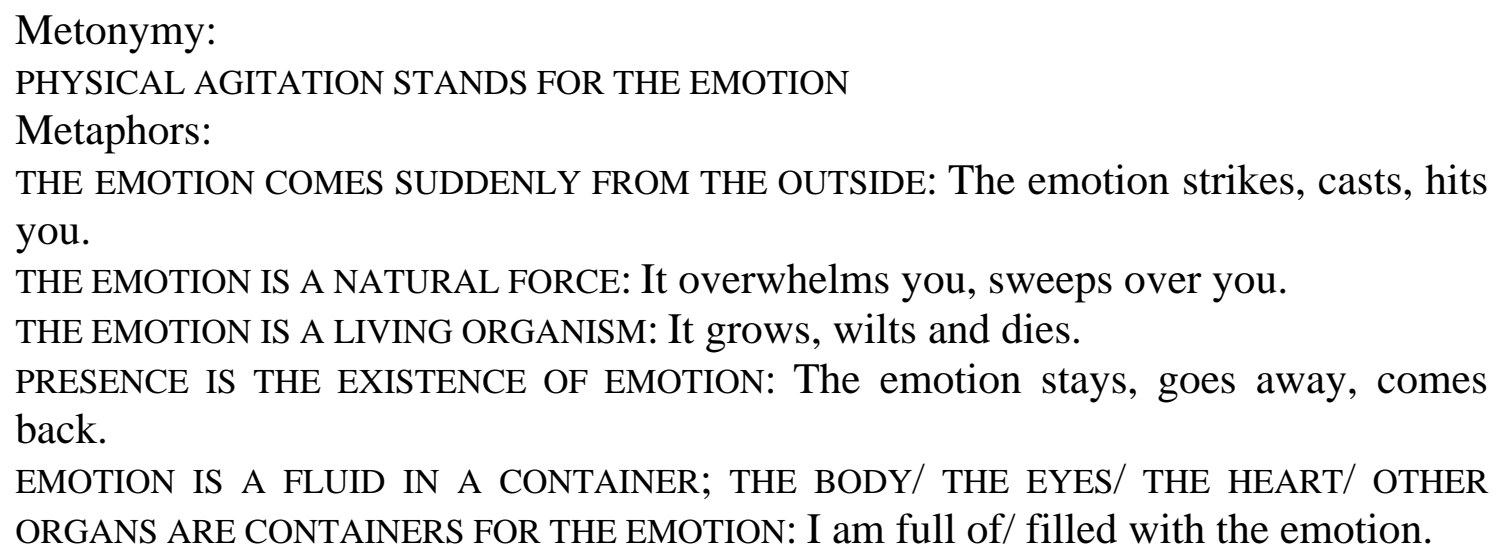

If we analyze them in detail, we can observe that the emotion goes through a series of phases: its arrival, which usually strikes; the effect it causes on the person while the emotion is present; and its disappearance. This finding has encouraged both cognitive psychologists and linguists to develop what has been called emotion scenarios. According to Ungerer and Schmid (1996: 140-142), the principle which governs these scenarios is that the emotion follows a sequence of different phases. These are: the cause of the emotion (stage 1), the emotion itself (stage 2), the (attempt of) control 
(stage 3), the loss of control (stage 4), and its consequences (stage 5). However, the different phases cannot be applied in the same way to the six categories of emotions considered to be basic (sadness, anger, disgust/hate, fear, joy/happiness and desire/love). They argue that they can be perfectly applied to anger and other negative emotions, but not to positive ones, such as happiness or love. We will show which phases can be applied to the category which concerns us.

As we will see through our analysis, the heart, as long as it represents the emotion, is conceptualized as a living organism. Therefore, we can establish the metaphor "THE HEART IS A LIVING ORGANISM". This is a personification, the second type of basic cognitive operation. Concretely, it is an ontological metaphor ${ }^{12}$, since an entity lacking that status, is personified. The clearest example of personification regarding the heart is its ability to talk, as the following expressions show:

Eng. My heart tells me

Sp. Me lo dice el corazón

It. Me lo dice il cuore

Fr. Le coeur me le dit

Ger. Mein Herz sagt es mir

The meaning of the Spanish expression “Tener una corazonada” can be deduced from this. It would be translated as follows:

Eng. To have a feeling/ a hunch (colloq)/ a presentiment (frml)

It. Avere un presentimento

Fr. Avoir un pressentiment

Ger. Ein Vorgefühl/ (Vor)ahnung haben

\section{The heart is the seat of the intellect}

The heart can carry out activities that require a special type of ability or mental capacity. Clear examples of that are the English and French expressions:

Eng. To learn by heart

Fr. Apprendre par cœur

The fact that we find common expressions in French and English can be a consequence of the Norman invasion that took place in England in 1066 (Battle of Hastings). The Normans brought many French influences, and French began to mix with Old English, becoming a more modern language. The Scandinavian influences were also important and Latin was still the language of the Church. All this had an effect on the English language and culture.

The previous expressions are translated as "aprender de memoria”, in Spanish; "imparare a memoria”, in Italian, and “auswendig lernen”, in German. Here the head is 
conceptualized as the container of memory, where we place information to make use of it when we need it. In other cases, such as the Spanish "recitar, saber, conocer, etc. de memoria", that capacity could be associated to affectivity, in the sense that we remember what we love or care for, what "touches our hearts".

The belief, already present in Ancient times, of the "mental" capacity of the heart, seen in English and French, also finds correspondence in the other languages. In German, we find the expression "Im Herz bewahren" (literally: "to keep something in the heart"), translated as "retain, not forget"; in Italian "ricordare/ricordarsi" means "to have present in the memory or "to call to memory", according to the metaphor "REMEMBERING IS BRINGING TO A PLACE" (cf. Santos \& Espinosa, 1996: 168). The Italian verb "accordare", which is translated in English as "to come to an agreement", and its derivatives "accordo: agreement; harmony" also come from the Latin root cor, cordis. Italian has an exact equivalence to the Spanish "recordar/se", "acordar/se" and their derivatives. We also find the opposite phenomenon, for instance, in Italian "scordare/ scordarsi" (the prefix s- has a privative meaning) means "forget, not remember"

The fact that the intellect is metonymically represented by the head (the whole for the part) has an evident physiological grounding, since the brain is located in the head, and therefore, it can be seen objectively as the place where abilities such as imagination, perception, creativity, logic, etc. can be found. However, it is not so clear that the heart has been considered the seat of certain intellectual faculties, as we have just seen. The popular psychology has located emotions in this body part (in Western cultures) and in the liver (in others), as a consequence of a social convention.

Nowadays, we know that the modern psychology locates the intellectual and the emotional functions in the brain. Reason and language are located in the left hemisphere, while emotions are placed in the right one and in the amygdala.

\section{The heart is the center/core of something}

As we know the heart is an organ situated in the chest and almost in the middle of the body. Besides, the function it carries out is vital for the human survival. That is why we refer to a central place as its heart, especially if that place is very important or has a lot of activity.

We find an exact equivalence in the five languages studied regarding that conceptualization of the heart as the center or core of something, for example:

Eng. The heart of the city

Sp. El corazón de la ciudad

It. Il cuore della città

Fr. Le coeur de la ville

Ger. Das Herz der Stadt 
Likewise, the middlefinger is called in Spanish “dedo corazón”. This learned word (derived from the Latin cor) is only found in Spanish. In the other languages there is not metaphorical projection:

It. Dito medio

Fr. Doigt du milieu

Ger. Mittelfinger

We also name the center or core of certain fruits as their hearts, as the "artichoke hearts":

Sp. Corazones de alcachofas.

It. Cuori di carciofi.

Fr. Coeurs d'artichauts.

Al. Artischockenherzen.

Curiously, in French there is the expression "avoir un coeur d'artichaut", that means "to be always falling in love":

Sp. Ser un enamoradizo.

It. Essere un farfallone/ un corteggiatore instancabile.

Ger. Ein Herz für viele haben/ ein weites Herz haben.

The explanation of the French expression derives from the multiple leaves that this vegetable has.

\section{The heart is the stomach}

So far we have seen that a metaphorical expression, derived from a conceptual metaphor, has the same equivalences in the other languages. Besides, we have highlighted that there are intercultural variations. On the one hand, we have pointed out that it may be the case that the underlying conceptual metaphor is the same, but its realizations in concrete lexical forms are different, i. e. there are different expressions or instantiations. Now, we are interested in showing that, on the other hand, there is also the possibility that the projection only takes place in one language. This is the case of the metaphor "THE HEART IS THE STOMACH", just found in French. It manifests itself mainly in the expression "avoir mal au coeur", which is translated in English as "to feel sick/ nauseous".

Rey and Chantreau (2002: 188) point out that it is possible that the Ancient physiology granted the heart the regulating function in the beginning of the digestion and the presence or absence of nausea. We hold a more precise explanation, since the Greek medicine designated the entry of the stomach kardia, term which corresponds in Latin to "cor", what would explain such expression in French. The Diccionario Griego- 
Español by Yarza (1998) cites "карбía” with the meanings of 1. Heart; 2. Cardias, upper orifice of the stomach; stomach; 3. Inside part of an object; 4 . Marrow of a tree. The Dictionnaire Grec-Français by Bailly (1985) includes in its meaning II. 1. orifice supérieur de l'estomac, d'où estomac; 2. intérieur d'une chose (d'une clepsydre). Likewise, it is included in the Dictionnaire étymologique de la langue grecque by Chantraine (1999), in which "карбía" is the "orifice supérieur de l'estomac, estomac". Finally, the Oxford Greek-English Lexicon (1996) includes it in the meaning II: "Cardiac orifice of the stomach". We could argue in favour of a metonymic basis of the expression "avoir mal au coeur", since kardia made reference to a part of the stomach and, therefore, there is a relation of "THE PART FOR THE WHOLE".

The term "cardias" also exists in Spanish. The DRAE (1984: 411) defines it as

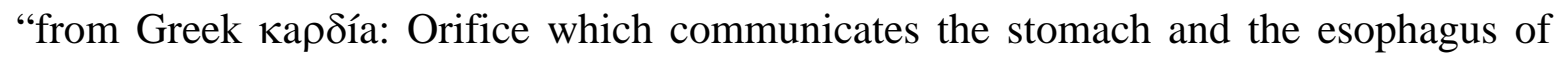
terrestrial vertebrates". In the Diccionario etimológico indoeuropeo de la lengua española by Roberts (1997), we find the root kerd- (*krd-), which includes the term cardias in its second meaning as "upper orifice of the stomach, heart-shaped" (here the metaphorical basis is evident), and the derivatives: cardialgia, cardiatelia, cardiectaxia, cardielcosis, cardiocele, cardiograma, cardiorrexia, cardioesclerosis, dexiocardia, endocardio, miocardio, neumatocardia and pericardio. However, in Spanish, it has just been kept as an anatomic term.

The expression we quoted previously, "avoir mal au coeur", is translated in the other languages as follows:

Sp. Tener náuseas

It. Avere la nausea

Ger. Jemandem ist schlecht/ übel

Other French expressions included in the Larousse Dictionary (1989) referred to this target domain are the following:

"Barbouiller o soulever le coeur: to turn sb's stomach".

"Manger de bon cœur: to eat with a good appetite".

Boch (1990: 104) cites the expression "mettre le coeur à l'envers", which also means "to turn sb's stomach". Rey and Chantreau (2002: 188) add "tourner sur le coeur", very similar to the previous one, since it means "to make sb's stomach turn" and "avoir le coeur au bord des lèvres: to feel sick", expression dated from the seventeenth century, unknown nowadays among native speakers. According to these authors, the nauseating dysphoria was interpreted as a rise of the heart towards the mouth, which would also explain the expressions "haut-le-coeur: náusea"13 and "avoir le coeur bien accroché", which applies to someone who does not get easily upset, tired or discouraged. From this same conception, we find the words "écoeurer" which means "to be sickening" or "to cloy" and, curiously, figuratively it means "to grow weary, to discourage, to dishearten" 
and the derivatives "écoeurement: disgust” (also "boredom” in the figurative sense) and "écoeurant: disgusting, repulsive”.

These expressions do not have correspondence in the other languages. However, we should point out that if we take a diachronic perspective into account, we can discover that such a conceptualization existed in other languages. For example, if we observe the meaning (4) of the OED, we can state that that conceptualization existed indeed, even though it has not survived. Specifically, we find the expression "next the heart", which means “on an empty stomach":

4. The stomach. Obs. or dial. Chiefly in phr. next the heart: on an empty stomach. 1542 UDALL Erasm. Apoph. (1877) 359 (D.) A newe founde diete, to drink wine in the morning nexte the harte.

1589 COGAN Haven Health (1636) 189, I have knowne some maidens to drinke vinegar next their heart to abate their colour.

1647 R. STAPYLTON Juvenal vi. 637 (D.) The Romans held it ominous to see a Blackamoore next their hearts in a morning.

1674 R. Godfrey Inj. Ab. Physic 116 So much is it the mode still to call the Stomach the Heart, that people frequently say their Hearts were at their Mouths, when on a sudden fright or surprisal their Stomach's have been mov'd.

The last expression, "their Hearts were at their Mouths", is still used. We can explain it thanks to that conceptualization. Therefore, a diachronic perspective is essential to explain the meaning of certain expressions nowadays. As Geeraerts and Grondelaers (1995: 173) point out: "It is necessary to take into account the historical background of our emotion concepts to get a clear picture of the present-day situation".

The last example included in meaning (4) of the $O E D$ referred to the target domain of the "stomach" is the following:

1825 FORBY Voc. E. Anglia, Heart, the stomach. “A pain at the heart” means the stomach-ache.

Therefore, we hold that this conceptualization is not completely "dead", since there are expressions nowadays that can be explained thanks to it. Such is the case of the word "Heartburn", as it is stated in the meaning (2) of the OED:

1. Burning of heart; fire of passion ${ }^{14}$. Rare.

2. An uneasy burning sensation in the lower part of the chest, due to putrefactive fermentation of the food in the stomach; cardialgy.

3. Rankling jealousy, discontent, or enmity.

In the other languages "heartburn” is translated as:

Sp. ardor/ acidez de estómago 
It. Pirosi/ bruciore di/ dello stomaco

Fr. Avoir des aigreurs/ les brûlures d’estomac

Ger. Magensäure

\section{Metonymic uses of heart}

The metonymy “THE HEART FOR THE PERSON" belongs to the metonymic model "THE BODY PART FOR THE PERSON". A clear example of it is the English expression "Heart to heart", used to express sincerity, which corresponds to the French "coeur à coeur ". There is no metonymic expression of this type in the other languages. We would translate it as "franco, íntimo o sincero", in Spanish; "franco, sincero", in Italian, and "Ganz ehrlich”, in German.

Another clear example is when the heart is used as an affectionate form of address: “¡Corazón mío!”, in Spanish; “mein Herz”, in German; “mon (petit) coeur”, in French; "cuore mio" "15, in Italian and "sweetheart" in English, language in which the heart is even conceptualized as something sweet.

In relation to the distinction between metaphor and metonymy, and, above all, regarding the metonymic basis of metaphor, we have to highlight that all body parts cannot be analysed in the same way in this respect. Hilpert (2006), in his article "Keeping an eye on the data: Metonymies and their Patterns", in which he carries out a detailed study of the lexeme eye in the British National Corpus, points out that only $2.7 \%$ of the examples found, containing the word eye, are metaphors; the rest are metonymies. According to him, this is due to the fact that some body parts, such as eye, are more liable to be subject of metonymic projections since they are conceptualized as objects. In relation with the study that we are undertaking, we hold that if we take into account the metonymy “THE BODY PART STANDS FOR THE ACTION CARRIED OUT BY IT”, we can understand why some body parts, such as hand, head, leg, etc. are more liable to be taken in a metonymic sense, compared to others such as the heart, since this is an internal entity and the instrumental sense we commented on previously is less clearly seen.

In the expressions subject of analysis, we find, on the one hand, the metonymy "THE PART FOR THE WHOLE” of the heart for the person, as we have just seen. Other times it is more difficult to establish a clear demarcation between metaphor and metonymy, as we will see now:

Eng. To win somebody's heart

Sp. Robarle el corazón a alguien

It. Conquistare il cuore di qualcuno

Fr. Gagner le coeur de quelqu'un

Ger. Jemandes Herz gewinnen

We think that these expressions have a metonymic basis, in the sense that the heart stands for the person. It is the "whole" person who is conquered, but the heart is what is 
given in a love relationship, since this is the place in which love is conventionally located. We could argue that even though the result is a metaphor, if we analyse in detail what has taken to that final conceptualization, we would discover that most of the metaphors have a metonymic basis. (Cf. Barcelona, 2001).

Kövecses (1986, 1988, 1990, 1991), Barcelona (1986, 2000), Lakoff (1987) and other linguists have written about the metonymic motivation of metaphors that express emotions such as anger, love, fear, happiness, pride, sadness etc., on the basis of the physiological reactions that they cause. For instance, a typical reaction is the change in heart rate, which can speed up as a consequence of a strong emotional impact ("His heart sped up when he saw her") or even stop ("My heart stopped when they told me the story"). In the first case, the metaphorical expression is based on the (physiological) metonymy "THE RISE OF HEART RATE IS EQUIVALENT TO THE INTENSITY OF THE EMOTION", so the higher the intensity of the emotion, the higher the heart rate. In the second case, the metonymy could be "A HEART STOP IS EQUIVALENT TO AN EMOTIONAL IMPACT”. Unlike the previous example, this second case is just an expression, since, in fact, the physiological reaction in question is not produced.

Kövecses (2005: 42) establishes the metaphor "A PERSON IN AN INTENSE EMOTIONAL STATE IS A PRESSURIZED CONTAINER". The main meaning focus is constituted by the difficulty in controlling a process, which, in turn, derives from the projection "the difficulty in controlling a (emotional) process projects itself in the difficulty in keeping a substance in a pressurized container". The intensity in heart rate can be caused by an unforeseen reaction or by a fright, for example, as it is shown in the following hyperbolic use:

Eng. To have one's heart in one's mouth

Sp. Tener el corazón en la boca ${ }^{16}$

It. Avere il cuore in gola

Fr. Avoir le coeur dans la gorge

Ger. Das Herz bis zum Hals schlagen

While English and Spanish project the heart in the mouth ${ }^{17}$, the other languages do it in the throat. In Spanish, it is even said "Tener el corazón en un puño" (literally: "to have one's heart in one's fist; meaning: "to have one's heart in one's throat), although the meaning is somehow different. In this case, a state of anguish, grief or depression is implied.

\section{Proverbs}

Metaphors constitute the basis of a great number of proverbs. With the heart we find the following:

Eng. Out of sight, out of mind ${ }^{18 .}$

Sp. Ojos que no ven, corazón que no siente. 
It. Lontano da occhi, lontano dal cuore ${ }^{19}$.

Fr. Loin des yeux, loin du cœur.

Ger. Aus den Augen, aus dem Sinn.

We can observe that there is equivalence in the Romance languages, which use the heart, whereas the Germanic languages use the intellect.

Other proverbs with a complete equivalence in the five languages are:

Eng. Out of the abundance/ fullness of the heart the mouth speaks.

Sp. De la abundancia del corazón habla la boca.

It. Per l'abbondanza del cuor la bocca parla.

Fr. De l'abondance du coeur la bouche parle.

Ger. Wes das Herz voll ist, des fließt/ geht der Mund über.

Eng. Cold hands, warm heart.

Sp. Manos frías, corazón caliente.

It. Mani fredde, cuore caldo.

Fr. Mains froides, coeur chaud.

Ger. Kalte Hände, warmes Herz.

We already explained the positive connotations of the adjective "warm" in section 3.2.3. The Moderne Deutsche Idiomatik (1996: 194) includes the expression "Der Mensch soll ein warmes Herz und einen kühlen Kopf haben", which is translated as "The man should have a warm heart and a cold head".

\section{Conclusions}

Our reflections determine the concept of "Idealized Cognitive Model" of the heart as the seat of emotions, mainly. This model is composed of several metaphors (and submetaphors derived from them) and metonymies, which are many times related, and constitute the cognitive folk model of the heart as the seat of emotions.

We have observed that the conceptualizations of the heart are very similar in the languages subject of study. Most of these similarities derive from universal aspects of the human body, what supports the idea of embodiment claimed by the cognitive theory (Lakoff, 1990, 1994). In this sense, we have seen that the heart can be conceptualized in the following ways:

- Seat of feelings, especially love.

The heart names other emotions or feelings (apart from love) such as:

- Worry or interest

- Sincerity

- Sadness

- Pity or sympathy 
- Affection

- Kindness or generosity

- Desire

- Courage

- The heart as an object of value

- The heart as the seat of intelligence

- The heart as core or central part

- The heart as a metonymy for the person

Therefore, in relation to the different target domains to which the source domain of the heart can be applied, we can establish the following metaphors and metonymies in our corpus:

\section{METAPHORS:}

- THE HEART IS A CONTAINER FOR THE EMOTIONS

This metaphor is divided in the following submetaphors:

O THE HEART IS LOVE

O THE HEART IS KINDNESS OR GENEROSITY

O THE HEART IS SINCERITY

O THE HEART IS AFFECTION

O THE HEART IS WORRY OR INTEREST

O THE HEART IS SADNESS

O THE HEART IS PITY OR SYMPATHY

O THE HEART IS DESIRE

O THE HEART IS COURAGE

- THE HEART IS A MATERIAL

- THE HEART IS A LIVING ORGANISM

- THE HEART IS A CONTAINER FOR INTELLIGENCE

- THE HEART IS THE CORE OR CENTRAL PART OF SOMETHING

\section{METONYMY:}

- THE HEART FOR THE PERSON

The differences can be established, on the one hand, on the basis of the different target domains to which the source domain "heart" can be applied. In this sense, we have seen that there is no equivalence of the metaphor "THE HEART IS THE STOMACH", in which the target domain "stomach" is only present in French, nowadays.

On the other hand, differences can also be established taking into account the different linguistic elaborations, i.e. there is the possibility that the conceptual metaphor is the same, but it is elaborated in a different way in the codes studied. There can be 
coincidence in some languages, but not in all of them, either because there is no metaphorical projection, as in Spanish "aprender de memoria", in Italian "imparare a memoria", and in German "auswendig lernen”, compared to English "learn by heart", and French "apprendre par cœur", languages in which there is metaphorical projection; or the Spanish metaphorical expression "dedo corazón" compared to English "Middlefinger", Italian "Dito medio", French "Doigt du milieu", and German "Mittelfinger", in which there is no metaphorical projection; either because the projection is given with a different body part: "tener el corazón en la boca", as in English "To have one's heart in one's mouth", opposed to Italian "Avere il cuore in gola”, French "Avoir le coeur dans la gorge", and German "Das Herz bis zum Hals hinaufschlagen", which project it in the "neck"; or either because the expression is unique in a particular language. Concerning this last case, during our thorough analysis of the lexicographical works consulted (cf. Bibliographical references), we have found a series of idiosyncratic expressions of each language subject of study that we show next:

Idiosyncratic English expressions:

- Change of heart.

- Cross my heart.

- In my heart of hearts.

- I couldn't find it in my heart (to forgive him, for instance).

- To wear one's heart on one's sleeve.

- His heart was in his boots.

- To cry one's heart out.

- To pour one's heart out.

- At heart's ease.

Idiosyncratic German expressions:

- Seinen Herzen Luft machen.

- Ein Herz und eine Seele sein.

- Seinen Herzen einen Sto $\beta$ geben.

- Dem Zuge seines Herzens folgen.

- Sein Herz in die Hand/ in beide Hände nehmen.

- jemandem ans Herz gewachsen sein.

- Kind unter dem Herzen tragen.

- Das Herz auf der Zunge tragen.

- Das Herz fiel/ rutschte ihm in die Hosen.

Idiosyncratic French expressions:

- Avoir mal au coeur.

- Barbouiller o soulever le coeur.

- Manger de bon cœur.

- Faire le joli cœur.

- Faire la bouche en cœur.

- S'en donner à coeur joie. 
- Avoir le coeur à l’ouvrage.

- Cache-coeur.

Idiosyncratic Italian expressions:

- Del cuore: favourite. For example: Squadra/ amico/ donna del cuore.

- (Fare qualcosa) a cuor leggero (leggermente senza riflettere, senza ben valutare i rischi (di un'impresa): without reflecting; without considering the risks of an enterprise).

- It also has the connotation of "happy”, as in English "lighthearted”.

- Avere in cuore (avere in animo, avere l'intenzione). For example: “Avere in cuore di chiedere perdono".

Idiosyncratic Spanish expressions:

- Tener el corazón en un puño.

- Encogérsele a alguien el corazón.

- No caberle a alguien el corazón en el pecho.

- Hacer de tripas corazón.

- Dedo corazón.

- Del corazón (applied to the press) ${ }^{20}$.

- Tener una corazonada.

- Tener uno su corazoncito.

Our study shows that, in most of the cases, there are parallelisms in the languages studied. The idiomatic expressions reflect a particular way of thinking, behaving and conceptualizing reality and experience. We have pointed out that there are curious coincidences in the figurative uses of these languages. Therefore, we should ask ourselves why this phenomenon takes place and why we find the same metaphors in different languages and cultures. We have noticed that there is a universal motivation for their origin which can be attributed to a series of universals related to the human body. The differences depend on the idiosyncrasy of each country and its language, what constitutes the basis of a particular idiomaticity.

If metaphor is grounded in the way our body and mind work, and we, as human beings, are all the same in this respect, therefore, most of the metaphors that we use should be very similar, and consequently universal, at least at the conceptual level. However, we have seen that this figure also reflects idiosyncratic cultural aspects, what makes us study it taking into account not only the cognitive aspect, but also the cultural one.

We hold that the mind, the body and the language, on the one hand (since they constitute the human being), and culture, on the other hand (since it determines him externally) constitute an indissoluble whole which must be taken into account once we study the phenomenon of metaphor. 


\section{Notes}

1. Obviously we are referring to the graphic representation with which it is traditionally associated.

2. Robin Turner, personal communication, 16 February, 2003.

3. Goddard (1996: 149ff) has made similar observations about the aboriginal language Yankunytjatjara.

4. The number of conceptual metaphors used for "HAPPINESS" is also very wide. In others like "ANGER", there seems to be a balance between the number of metaphors and metonyms employed. In contrast, in the category "FEAR" metonyms predominate.

5. Niemeier (1997: 93) points out that the German expression is conceptualized in a different way, as it does not exclusively refer to positive emotions.

6. The Spanish expression "me sangra el corazón”, the Italian "mi sanguina il cuore” and the French "le coeur me saigne" are considered to be very literary, that is the reason why we have not included them here.

7. Even "At heart's ease".

8. The expression "avoir le coeur à l'ouvrage: to have one's heart in one's work" derives from this one.

9. It corresponds to the French expression "Faire contre mauvaise fortune bon coeur". The German translate it as "den Kopf oben halten" ("to keep one's head up"). Covarrubias (1993[1611]) points out that "hacer de tripas corazón" means "to show a lot of courage, while being a coward inside". Buitrago (1997: 197) maintains that when the heart is broken and is not capable of overcoming a difficult situation, the guts, i. e., other entrails have to take its place and do its function. According to this author, the expression means to make an effort to conceal fear, tiredness or the feeling of sadness to continue acting normal. In a similar way, Candón and Bonnet (2000: 177) maintain that this expression means to hide fear, shyness or feeling; to pretend to be in good spirits, even though, we can be scared to death deep inside.

10. We also find the same negative connotations associated to cold with other body parts, as in English "To give someone the cold shoulder (treat someone with contempt or neglect)".

11. Cf. Searle (1995: 324) about the emotional metaphorization as heat, and not emotional as cold, where he shows the cultural origin of these metaphors.

12. Lakoff and Johnson (1980: 25) refer to ontological metaphors as follows: “... our experience with physical objects (especially our own bodies) provide the basis for an extraordinary wide variety of ontological metaphors, that is, ways of viewing events, activities, emotions, ideas, etc., as entities and substances".

13. This expression should not be mistaken for "Haut le coeurs!". In this one "coeur" would not make reference to the heart, but to spirit, courage (cf. section 3.1.6). It is a metonymy which we would translate as "up the hearts!. The plural of "heart" refers to people.

14. This meaning relates to the metaphor "LOVE IS FIRE". Connected to this, we find the expression "to set all hearts on fire", which refers to someone who inspires love in many people.

15. In Italian, nevertheless, expressions such as "caro mio" or "tesoro mio" are more common.

16. Or another like "darle a uno un vuelco el corazón: someone's heart misses a beat”.

17. The Spanish expression "Parecía que se me iba a salir el corazón por la boca" constitutes another example of that. 
18. Variants: "What the eye doesn't see, the heart doesn't grieve over", "Wise men have their mouth in their heart, fools their heart in their mouth". The last one corresponds to the French "Les sages ont la bouche dans le coeur et les fous le coeur dans la bouche" and the Italian "I saggi hanno la bocca nel cuore, e i matti il cuore in bocca".

Cf. Lat. Ex abundantia cordis.

19. Variant: "Occhio non vede, cuore non duole".

20. The press which gathers pieces of news related to celebrities, especially concerning their private life: "Revista del corazón". We should not mistake this expression for the Italian "del cuore", as in "Squadra/ amico del cuore" which is translated as "favorite team/friend".

\section{References}

Bailly, Anatole (1985): Dictionnaire Grec-Français. Paris: Hachette, D. L.

Baldauf, Christa J. (1996): “Konzept und Metapher- Präzisierung einer vagen Beziehung”. Linguistische Berichte. 166: 461-482.

- (1997): Metapher und Kognition. Grundlagen einer neuen Theorie der Alltagsmetapher. Fráncfort del Meno: Peter Lang.

Bauer, Anton (1973): Das melanesische und chinesische Pidginenglish. Regensburg: Carl.

Barcelona, Antonio (1986): "On the concept of depression in American English: A cognitive approach”. Revista Canaria de Estudios Ingleses 12: 7-33.

. (2000): "On the plausibility of claiming a metonymic motivation for conceptual metaphor”. In A. Barcelona, ed., Metaphor and Metonymy at the Crossroads. A Cognitive Perspective. Berlin/ New York: Mouton de Gruyter, 31-58.

. (2001): "On the systematic contrastive analysis of conceptual metaphors: case studies and proposed methodology". In M. Pütz, S. Niemeier and R. Dirven, eds., Applied Cognitive Linguistics II: Language Pedagogy. Berlin: Mouton de Gruyter, 117-146.

Boch, Raoul (1990): La boîte à images. Dizionario fraseologico delle locuzioni francesi. Bologna: Zanichelli.

Brugman, Claudia (1988 [1981]): “The Story of "over"; Polysemy, Semantics and the Structure of the Lexicon”. MA thesis, University of California, Berkeley. New York: Garland.

Brugman, Claudia and George Lakoff (1988) "Cognitive topology and lexical networks". In S. Small, G. Cottrell and M. Tannenhaus, eds., Lexical Ambiguity Resolution. San Mateo, CA: Morgan Kaufman, 447-507.

Buitrago Jiménez, Alberto (1997): Diccionario de dichos y frases hechas. Madrid: Espasa.

Candón Margarita and Elena Bonnet (2000): A buen entendedor... Diccionario de frases hechas de la lengua castellana. Madrid: del Taller de Mario Muchnik.

Carvajal, Carol Styles and Jane Horwood (eds.) (2001): Oxford Spanish Dictionary. $2^{\text {nd }}$ ed. Oxford: Oxford University Press.

Chantraine, Pierre (ed.) (1999): Dictionnaire étymologique de la langue grecque: histoire des mots. Paris: Klincksieck.

Covarrubias, Sebastián (1993 [1611]): Tesoro de la lengua castellana o española. 3rd ed. by Martín de Riquer. Barcelona: Alta Fulla.

Deignan, Alice (1995): Collins Cobuild English Guides, 7: Metaphor. London: Harper Collins. (1999): "Corpus-based research into metaphor". In L. Cameron and G. Low, eds., Researching and Applying Metaphor. Cambridge: Cambridge University Press, 177-199.

Diccionario crítico etimológico castellano e hispánico (1980). Madrid, Gredos. 
Dobrovol'skij, Dimitrij O. (1995): Kognitive Aspekte der Idiom-Semantik. Studien zumThesaurus deutscher Idiome. Tubinga: Gunter Narr.

DRAE. (1984): Madrid: Real Academia Española.

Enfield, Nick and Anna Wierzbicka (2002): "Introduction: The body in description of emotion”. Pragmatics and Cognition 10 (1-2): 1-24.

Escandell Vidal, María Victoria (1993): Introducción a la pragmática. Barcelona: Anthropos.

García Pelayo, Ramón and Jean Testas (eds.) (1989): Dictionnaire moderne FrançaisEspagnol/ Español-Francés. Paris: Larousse.

Geeraerts, Dirk and Stefan Grondelaers (1995): "Looking Back At Anger: Cultural Traditions and Metaphorical Patterns”. In J. Taylor and R. E. MacLaury, eds., Language and the Construal of the World. Berlin: Mouton de Gruyter, 153-180.

Goddard, Cliff (1996): “Cross-linguistic research on metaphor”. Language \& Communication 16 (2): 145-151.

Grande Dizionario di Spagnolo (Spagnolo-Italiano/ Italiano-Spagnolo) (2004). Milano: Hoepli.

Hilpert, Martin (2006): “Keeping an eye on the data: Metonymies and their Patterns". In A. Stefanowitsch and S. T. Gries, eds., Corpora in cognitive linguistics. Vol 1. Metaphor and metonymy. Berlin/ Nueva York: Mouton de Gruyter, 123-152.

Ibarretxe-Antuñano, Blanca Iraide (1999): “Metaphorical mappings in the sense of smell”. In G. Steen and R. Gibbs, eds., Metaphor in Cognitive Linguistics. Amsterdam and Philadelphia: John Benjamins, 29-45.

Kövecses, Zoltán (1986): Metaphors of Anger, Pride, and Love: A Lexical Approach to the Structure of Concepts. Amsterdam: John Benjamins.

. (1988): The Language of Love. The Semantics of Passion in Conversational English. Lewisburg, PA: Bucknell University Press.

(1990): Emotion Concepts. New York: Springer-Verlag.

(1991): "Happiness: A definitional effort”. Metaphor and Symbolic Activity 6: 29-46.

(2000): Metaphor and Emotion. Language, Culture and Body in Human Feeling.

Cambridge and New York: Cambridge University Press.

(2002): Metaphor. A practical introduction. New York: Oxford University Press.

. (2005): Metaphor in Culture. Universality and Variation. Cambridge: CUP.

Lakoff, George (1987): Women, Fire, and Dangerous Things: What Categories Reveal about the Mind. Chicago: Chicago University Press.

. (1990): “The invariance hypothesis: Is abstract reasoning based on image-schemas?”. Cognitive Linguistics 1 (1): 39-74.

(1993): “The contemporary theory of metaphor”. In A. Ortony, ed., Metaphor and Thought. $2^{a}$ ed. Cambridge: Cambridge University Press, 202-251.

. (1994): "What is a conceptual system?". In W. F. Overton and D. S. Palermo, eds., The Nature and Ontogenesis of Meaning. Hillsdale, NJ: Lawrence Erlbaum, 41-90.

Lakoff, George and Mark Johnson (1980): Metaphors We Live By. Chicago: Chicago University Press.

Martín Morillas, José Manuel and Juan Carmelo Pérez Rull (1998): Semántica cognitiva intercultural. Granada: Granada Lingvistica y Método Ediciones.

Niemeier, Susanne (1997): "To have one's heart in the right place - metonymic and metaphorical evidence for the folk model of the heart as the site of emotions in English”. In B. Smieja and M. Tasch, eds., Human Contact through Language and Linguistics. Frankfurt am Main/ New York: Peter Lang, 87-106. 
. (2000): "Straight from the heart - metonymic and metaphorical explorations". In A. Barcelona, ed., Metaphor and Metonymy at the Crossroads. Berlin: Mouton de Gruyter, 195-213.

Oxford English Dictionary (OED). (1992). $2^{\mathrm{a}}$ ed. Oxford: Oxford University Press.

Oxford Greek-English Lexicon. (1996). Oxford: Clarendon Press.

Rey, Alain and Sophie Chantreau (2002) : Dictionnaire des Expressions et Locutions. ${ }^{\mathrm{a}}$ ed. Paris: Le Robert.

Roberts, Edward A. and Bárbara Pastor (1997): Diccionario etimológico indoeuropeo de la lengua española. Madrid: Alianza Editorial.

Rosch, Eleanor (1973): “On the Internal Structure of Perceptual and Semantic Categories”. In T. E. Moore, ed., Cognitive Development and the Acquisition of Language. New York: Academic Press, 111-144.

. (1975): “Cognitive representations in semantic categories”. Journal of Experimental Psychology: General, 104: 192-233.

. (1977): "Human categorization". In N. Warren, ed., Studies in Cross-Cultural Psychology. Vol. 1. New York: Academic Press, 3-49.

. (1978): "Principles of categorization”. In E. Rosch and B. B. Lloyd, eds., Cognition and Categorization. Hillsdale, NJ: Erlbaum, 27-48.

Rosch, Eleanor and Carolyn B. Mervis (1975): "Family resemblances: Studies in the internal structure of categories”. Cognitive Psychology 7: 573-605.

Rosch, Eleanor et al. (1976): "Basic objects in natural categories”. Cognitive Psychology 8: 382-439.

Ruiz de Mendoza Ibánez, Francisco J. (1999): Introducción a la Teoría Cognitiva de la Metonimia. Granada: Granada Lingvistica y Método Ediciones.

Sandra, Dominiek (1998): "What linguists can and can't tell you about the human mind: A reply to Croft”. Cognitive Linguistics 9 (4): 361-478.

. and Sally Rice (1995): "Network analyses of prepositional meaning: Mirroring whose mind - the linguist's or the language user's?”. Cognitive Linguistics 6 (1): 89-130.

Santos Domínguez, Luis Antonio and Rosa M. Espinosa Elorza (1996): Manual de semántica histórica. Madrid: Síntesis.

Searle, John R. (1995): The Construction of Social Reality. New York: The Free Press.

Soriano, Cristina (2003): "Some Anger Metaphors in Spanish and English. A Contrastive Review”. International Journal of Contrastive Studies 3 (2): 107-122.

Ungerer, Friederich and Hans Jörg Schmid (1996): An Introduction to Cognitive Linguistics. London: Longman.

Varela, Fernando and Hugo Kubarth (eds.) (1996): Diccionario fraseológico del español moderno. Madrid: Gredos.

Wolf, Friederich (1996): Moderne Deutsche Idiomatik. München: Heuber.

Yarza, Sebastián (ed.) (1998): Diccionario Griego- Español. Barcelona: Sopena. 